Acta Agroph., 2018, 25(3), 261-275

doi: $10.31545 /$ aagr/93584

\title{
STUDY ON CHANGES AND RELATIONSHIPS OF PHYSIOLOGICAL AND MORPHOLOGICAL PARAMETERS OF RYE SUBJECTED TO SOIL DROUGHT STRESS*
}

\author{
Katarzyna Monika Malinowska1, Beata Myśków², Ilona Czyczyło-Mysza $a^{3}$ \\ Magdalena Góralska \\ ${ }^{1}$ Department of Plant Physiology and Biochemistry \\ West-Pomeranian University of Technology in Szczecin \\ ul. Słowackiego 17, 71-434 Szczecin, Poland \\ ${ }^{2}$ Department of Plant Genetics, Breeding and Biotechnology \\ West-Pomeranian University of Technology in Szczecin \\ ul. Słowackiego 17, 71-434 Szczecin, Poland \\ ${ }^{3}$ The F. Górski Institute of Plant Physiology PAS \\ ul. Niezapominajek 21, 30-239 Kraków, Poland
}

\begin{abstract}
The study was aimed at the evaluation of the impact of drought stress on the efficiency of the photosynthetic apparatus of rye inbred line GULbw, evaluated based on measurements of chlorophyll fluorescence and gas exchange parameters, water balance, assimilation pigments and morphological characters, and by the analysis of the relationship between these parameters. The experiment was performed on the rye inbred line GULbw (original name: Gülzow 661-67, accession numbers: GueR 412; R 1599), obtained from the gene bank of The Federal ex situ Gene Bank for Agricultural and Horticultural Crop Species of The Leibniz Institute of Plant Genetics and Crop Plant Research Gatersleben. Because of drought, the PSII (photosystem PS II) performance index was reduced, and the decrease tendency of the PI (overall performance index of PSII) value intensified with the length of the stress period. The tested rye line did not exhibit any considerable variability of the maximum quantum efficiency of the PS II (Fv/Fm). Significant differences in the intensity of transpiration, stomatal conductance, and substomatal concentration of $\mathrm{CO}_{2}$ was determined on day 18 of drought. A significant positive value of the correlation coefficient $r$ was found between PLSN, LSW, LSGN, LSGW, and E, gs, ci.
\end{abstract}

Key w ords: morphology, photosynthesis, Secale cereale L.

* This work was supported by the National Science Centre, Poland, under grant 2015/17/B/ NZ9/01694 


\section{LIST OF SYMBOLS USED}

$\mathrm{C}$ - control, well-watered variant of the experiment; $\mathrm{c}_{\mathrm{i}}$ - intercellular $\mathrm{CO}_{2}$ concentration; D - drought, water deficit variant of the experiment; $\mathrm{E}$ - transpiration rate; $\mathrm{Fm}$ - maximal fluorescence; $\mathrm{Fv}$ - maximal variable fluorescence; $\mathrm{Fv} / \mathrm{Fm}$ - maximal quantum yield of PSII photochemistry; gs - stomatal conductance; LSDW - lateral stalk spikes dry weight; LSGN - productive lateral spikes grain number; LSGW - productive lateral spikes grain weight; LSN - lateral stalk number; LSTGW - productive lateral spikes thousand grain weight; LSW - productive lateral spikes weight; MSGN - main stem grain number; MSGW - main stem grain weight; MSSL - main stem spike length; MSSW -main stem spike weight; MSTGW-main stem thousand grain weight; MSW - main stem dry weight; PC1 - principal component 1 , PC2 - principal component 2; PH - plant height; PI - overall performance index of PSII; PL - peduncle length; PLSN - productive lateral spike number; Pn-net photosynthetic rate; PW - plant dry weight; RWC - relative water content; SN - stalk number; $\mathrm{T}_{\mathrm{FM}}$ - time required to reach maximal fluorescence; WSD - water saturation deficit; WUE - photosynthetic index of water use efficiency; WUEI - instantaneous photosynthetic index of water use efficiency.

\section{INTRODUCTION}

Drought is one of the most important environmental factors limiting the growth and the productivity of crops. Plant response to water stress is a complex process, leading to significant physiological and biochemical changes and eventually to morphological changes (Mishra et al. 2012). Water deficiency disables the efficient use of the obtained light energy, through increased dispersion caused by heat and enhanced fluorescence (Cetner et al. 2014). To evaluate plant reaction to water stress, physiological, biochemical, and morphological plant parameters are used, chlorophyll fluorescence tests that allow recording the changes taking place in the photosynthetic apparatus are performed, and the plant physiological status is determined (Yordanov et al. 2000, Mahajan and Tuteja 2005, Richards 2006, Anjum et al. 2011, Desotgiu et al. 2012, Kalaji et al. 2012).

Rye is considered to be the most drought-resistant cereal. A parameter which indicates this feature can be the water-use-per-dry-weight unit - rye requires as much as $20-30 \%$ less water than wheat (Starzycki 1976). Thus, rye could constitute a valuable source of information for studying resistance mechanisms, and yet it is weakly studied in this field, particularly in the aspect of the course of photosynthesis. 
In the climate of our country, lack of water is one of the most important factors limiting crop yields. These conditions force us to ask what phenotypes of cereals will ensure stable and high yields in areas threatened with drought.

The study was aimed at the evaluation of the impact of drought stress on the efficiency of the photosynthetic apparatus of rye inbred line GULbw, evaluated based on measurements of chlorophyll fluorescence and gas exchange parameters, water balance, assimilation pigments and morphological characters, and by the analysis of the relationships between these parameters. Verification of the inbred line of GULbw rye, understanding the physiological basis of its resistance to drought stress, will make it possible to initially determine the suitability of this variety in areas threatened by drought.

\section{MATERIALS AND METHODS}

\section{Plant material and growth conditions}

The experiment was performed on the rye inbred line GULbw (original name: Gülzow 661-67, accession numbers: GueR 412; R 1599), obtained from the gene bank of The Federal ex situ Gene Bank for Agricultural and Horticultural Crop Species of The Leibniz Institute of Plant Genetics and Crop Plant Research (IPK) Gatersleben, Germany. This line is characteristic due to its green colour, which is unusual for typical, glaucous plants of rye. GULbw was grown in a vegetation hall of the West Pomeranian University of Technology in Szczecin, Poland $\left(53.45^{\circ} \mathrm{N}, 14.53^{\circ} \mathrm{E}\right)$.

Seeds were sown in January, singly, in pots ( $15 \mathrm{~cm}$ diameter, $20 \mathrm{~cm}$ high) filled with a mixture of soil and sand in equal proportions by volume. The pots were filled with the same soil mass $(3.8 \mathrm{~kg})$ and same water content. Initially, plants were grown in a greenhouse at the temperature of $15^{\circ} \mathrm{C}$ for first three weeks, followed by a gradually decreasing temperature until it was close to atmospheric conditions. Further vegetation proceeded under natural conditions of the winter-spring period (February-September), with natural daylight duration, under a foil tunnel.

Two irrigation regimes were applied: well-watered control and a water-limited variant, referred to as drought. The plants were watered with an appropriate volume of water, on the basis of plant viability, soil appearance, and soil moisture that is measured as volumetric water content (VWC) (TDR 100 Soil Moisture Meter, Spectrum Technologies, Inc.). In our study, $60-70 \%$ VWC was adopted as well-watered control and $20-30 \% \mathrm{VWC}$ as drought. For the drought treatment, the watering was limited to $20-30 \%$ VWC for 18 days. The period of drought coincided with the phases of tillering, shooting, heading, and the beginning of flowering. Each variant of the experiment was represented by five plants. 


\section{Physiological determinations}

Determinations of physiological parameters were conducted on two dates: on day 12 and 18 of drought. Measurements of the gas exchange parameters $\left(\mathrm{CO}_{2}\right.$ assimilation, transpiration, stomatal conductance, and substomatal concentration of $\mathrm{CO}_{2}$ ) were conducted (in five replicates) on leaves with the use of a mobile gas analyser TPS-2, operating in an open system with PLC-4 chamber. The following conditions were adopted in the analyser cuvette: constant carbon dioxide supply, humidity equal to the ambient humidity, and illumination equal to 2053 PAR $\left(\mu \mathrm{mol} \mathrm{m} \mathrm{m}^{-2}\right.$ ), supplied through the light attached to the cuvette.

Determination of the induction of chlorophyll fluorescence was performed using a Handy PEA fluorimeter (Hansatech, UK). The measurements were performed in the mid-portion of the leaf, with its prior shading with a clip for about 20 minutes. The measurement was performed on eight leaves of each analysed plant in control $(n=40)$ and dried $(n=40)$. Based on the measurements of chlorophyll fluorescence, the energy flow theory in PSII and using the OJIP test proposed by Strasser, the following parameters of chlorophyll fluorescence kinetics were calculated and analysed: $\mathrm{F}_{\mathrm{V}} / \mathrm{F}_{\mathrm{M}}$ - maximal photochemical efficiency of PSII, PI - overall performance index of PSII, $\mathrm{T}_{\mathrm{FM}}$ - time needed to reach the maximal chlorophyll fluorescence, and $\mathrm{F}_{\mathrm{V}}$ - variable fluorescence.

Based on the obtained results of the assimilation intensity, transpiration and stomatal conductance, the photosynthetic index of water use efficiency (WUE) and instantaneous photosynthetic index of water use efficiency (WUEI) were calculated.

The determination of the content of assimilation pigments (chlorophyll "a" and "b" and carotenoids) was conducted on the same leaves for which the gas exchange parameters were defined. The analyses were conducted in five replicates of each analysed plant in the control $(\mathrm{n}=25)$ and dried $(\mathrm{n}=25)$. The chlorophyll content was determined using the method of Arnon et al. (1956) with Lichtenthaler modification (1987), whereas for the carotenoid content, the Hager and Meyer-Bethenrath method was used (1966).

The relative water content index (RWC) and water saturation deficit (WSD) were determined in accordance with Bandurska (1991).

\section{Agronomic traits}

At final maturity, the plants were cut at the soil surface, weighed, and separated from the main shoot and remaining parts. For each plant, the following parameters were measured or counted: stalk number (SN), plant dry weight (PW), plant height $(\mathrm{PH})$, peduncle length (PL), main stem dry weight (MSW), main stem spike length (MSSL), main stem spike weight (MSSW), main stem grain number (MSGN), main stem grain weight (MSGW), main stem thousand grain weight (MSTGW), lateral 
stalk spikes dry weight (LSDW), number of lateral stalks with spikes (LSN), number of productive lateral spikes (PLSN, which means spikes with at least one grain), productive lateral spikes weight (LSW), productive lateral spikes grain number (LSGN), productive lateral spikes grain weight (LSGW), productive lateral spikes thousand grain weight (LSTGW).

\section{Statistical analyses}

Presented results are based on 5 biological and 5-8 technical replicates. Data were analysed using the STATISTICA 12.0 software package (StatSoft, Inc., USA). Significant differences were calculated using Duncan's multiple range test at $\mathrm{p}=0.01$. Pearson linear correlation ( $\mathrm{r}$ ) was computed $(\mathrm{p}=0.01)$ to test the significance between the parameter correlations. Principal Component Analysis (PCA) was performed.

\section{RESULTS AND DISCUSSION}

The reaction of plants to water deficiency is complex and it is related to the coordination of numerous biochemical chains leading to the expression of genes responsible for the adaptation to stress conditions (Bray 1997, Neill and Burnett 1999). Photosynthesis is one of the physiological processes that is strongly modified by water stress, thus the research of its course is used to evaluate plants in reaction to the stress (Rekika et al. 1998, Desotgiu et al. 2012, Kalaji et al. 2012). Restriction of $\mathrm{CO}_{2}$ assimilation and transpiration resulting from water stress may be due to the decreased aperture or closing of the stomata, caused by the difference between external and internal humidity of a leaf, as well as increased synthesis of the abscisic acid, causing a decrease of stomatal cell turgor pressure (Popova et al. 2000). Apart from the inhibition of these processes, caused by the closing of the stomata, water stress contributes to a reduction of photosynthesis intensity through reduced activity of enzymes participating in the carboxylation process, restriction of electron transport by PS II, destruction of the photosystem structures, and by a reduction of chlorophyll and carotenoid content (Yordanov et al. 2000, Jaleel et al. 2009, Zlatev 2009). Reduction of the amount of assimilation pigments may impact the reduction of photosynthesis intensity (Anjum et al. 2011).

In the conducted study, significant differences between chlorophyll a and total chlorophyll content were observed between the tested rye lines in the control and those subjected to stress conditions. The tendencies for the changes of the content of assimilation pigments in leaves of the tested rye line in the control and those subjected to stress conditions were similar. The content of assimilation pigments in the GULbw line was reduced in the course of drought. The mean values of total chlorophyll and carotenoids on day 18 of drought were $1855 \mu \mathrm{g} \mathrm{g}^{-1}$ d.w. and $808 \mu \mathrm{g} \mathrm{g}^{-1}$ d.w. and were lower by 21.2 and $35.3 \%$, respectively, relative to their concentration on 
day 12 of drought (Fig. 1). The content of chlorophyll a, chlorophyll b, and carotenoids in GULbw leaves on day 18 of drought constituted 57.3, 55.9, and 46.6\% of the amount of these pigments in the leaves of the control plant, respectively (Fig. 1). Czyczyło-Mysza and Myśków (2017), after four weeks of drought, did not determine significant differences in the content of total chlorophyll in two rye inbred lines. A reduced concentration of chlorophyll in tissues of plants growing in drought conditions was demonstrated by Ranjbarfordoei et al. (2000). Anjum et al. (2003) showed that water stress changed the ratio of chlorophyll a and $\mathrm{b}$. A reduction in chlorophyll content was reported in drought stressed cotton (Massacci et al. 2008). Kiani et al.(2008) revealed that the chlorophyll content decreased to a significant level at higher water deficits in sunflower plants. Arji and Arzani (2008) showed that the amount of chlorophyll a and $b$ significantly decreased under drought stress. Water stress also has the ability to reduce concentrations of chlorophylls and carotenoids, primarily by the production of ROS (reactive oxygen species) in the thylakoids. Both chlorophyll a and b are prone to soil drying. Low concentrations of photosynthetic pigments can directly limit photosynthetic potential (Anjum et al. 2011). Carotenoids play additional roles and partially help the plants to withstand drought stress. Carotenes are very susceptible to oxidative damage (Jaleel et al. 2009).

The share of stomatal regulation in controlling the photosynthesis and transpiration processes depends on the stress intensity (Yordanov et al. 2003). Exposure of the tested rye line to drought stress caused considerable reduction of $\mathrm{CO}_{2}$ assimilation and transpiration processes. Differences in parameters of gas exchange on the dates of the drought period were observed. On day 12 and 18 of drought, significant differences in the intensity of $\mathrm{CO}_{2}$ assimilation were determined in the WUE and WUEI between the tested rye lines in the control and those subjected to stress conditions. Significant differences in the intensity of transpiration, stomatal conductance and substomatal concentration of $\mathrm{CO}_{2}$ were determined on day 18 of drought. The reduction of transpiration intensity had a more subdued character (Fig. 1). Net photosynthesis and transpiration intensity in the GULbw line in drought conditions was reduced by $24.5 \%$ and $22.3 \%$, respectively, relative to the intensity of these processes in the control plant (Fig. 1). Net photosynthesis and transpiration intensity depended on stomatal conductance, to a large degree. Stomatal conductance in the tested rye lines in drought conditions was reduced by $17 \%$ compared to the control (Fig. 1). Significant positive relationship among net photosynthesis, transpiration, and stomatal conductance was determined (Tab. 1). In stress conditions, the concentration of substomatal $\mathrm{CO}_{2}$ was $77.5 \%$ as compared to the control (Fig. 1). The intensity of net assimilation was significantly dependent on the concentration of substomatal $\mathrm{CO}_{2}$ (Table). A reduction of stomatal conductance in raspberries in drought conditions was observed by Stoll et al. (2002) and Klamkowski et al. (2015). Mishra et al. (2012) determined that a prolonged stress leads to the closing of stomata and to 

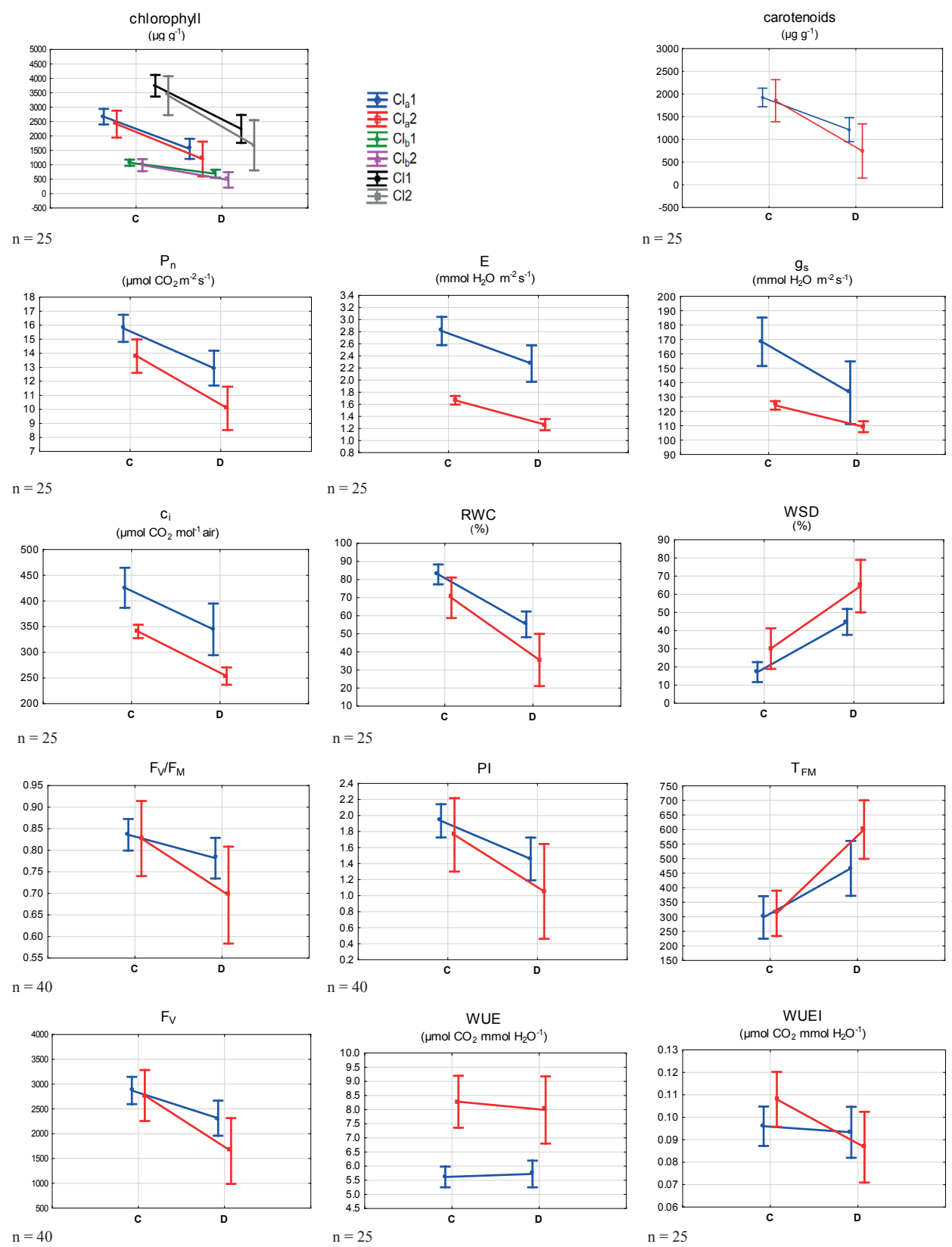

Fig. 1. Differences of selected physiological parameters between rye inbred lines of GULbw plants grown in well-watered conditions (C) and under drought stress (D). Blue line - measurements made after 12 days of drought; red line - measurements made after 18 days of drought; vertical lines - 0.95 confidence levels 
a reduction of the intensity of $\mathrm{CO}_{2}$ assimilation. Research conducted by Olszewska (2004) on the activity of assimilation of two white clover cultivars in water stress conditions exhibited a reduction in the activity of the process. Olszewski et al. (2007) demonstrated that the gas exchange indices, which include the intensity of photosynthesis, transpiration, and intercellular concentration of $\mathrm{CO}_{2}$ and the stomatal conductance, in two winter wheat cultivars were reduced in water deficit conditions. Kocoń (2006) obtained an average of 30\% lower values of photosynthesis, transpiration and stomatal conductance intensity in three cultivars of spring wheat in drought conditions. Restriction of $\mathrm{CO}_{2}$ assimilation in conditions of water stress in raspberry was obtained by Morales et al. (2013) and Klamkowski et al. (2015). In the present study, for the tested rye line on day 12 of drought, higher values of WUE were obtained, in comparison to the control conditions (Fig.1). Similar relationships were determined by Jaroszewska et al. (2011) for cherry, and by Olszewska and Gregorczyk (2013) for different grass species subjected to water stress. The increase of water use by plants is of particular importance to maintain their yielding level in drought conditions (Blum 2009).

Table 1. Physiological and morphological parameters of rye inbred line GULbw whose values measured at control and drought conditions showed statistically significant differences, according to Duncan test at $\mathrm{p}=0.01$

\begin{tabular}{|c|c|c|c|c|c|c|c|c|c|c|c|}
\hline 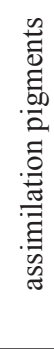 & $\begin{array}{l}\text { Cla1 } \\
\text { Cla2 } \\
\text { Clb1 } \\
\text { Clb2 } \\
\text { Cl1 } \\
\text { Cl2 } \\
\text { Ct1 } \\
\text { Ct2 }\end{array}$ & 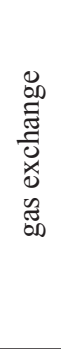 & $\begin{array}{l}\mathbf{P}_{\mathrm{n} 1} \\
\mathbf{P}_{\mathrm{n} 2} \\
\mathrm{E} 1 \\
\mathbf{E 2} \\
\mathrm{g}_{\mathrm{s} 1} \\
\mathbf{g}_{\mathrm{s} 2} \\
\mathrm{c}_{\mathrm{i} 1} \\
\mathbf{c}_{\mathrm{i} 2}\end{array}$ & 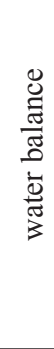 & $\begin{array}{l}\text { WUE1 } \\
\text { WUE2 } \\
\text { WUEI1 } \\
\text { WUEI2 } \\
\text { RWC1 } \\
\text { RWC2 } \\
\text { WSD1 } \\
\text { WSD2 }\end{array}$ & 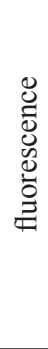 & $\begin{array}{l}\mathrm{F}_{\mathrm{V}} / \mathrm{F}_{\mathrm{M} 1} \\
\mathrm{~F}_{\mathrm{V}} / \mathrm{F}_{\mathrm{M} 2} \\
\mathrm{PI} 1 \\
\mathrm{PI} 2 \\
\mathrm{~T}_{\mathrm{FM} 1} \\
\mathrm{~T}_{\mathrm{FM} 2} \\
\mathrm{~F}_{\mathrm{V} 1} \\
\mathrm{~F}_{\mathrm{V} 2}\end{array}$ & 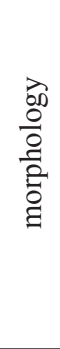 & $\begin{array}{l}\text { SN } \\
\text { PW } \\
\text { PH } \\
\text { PL } \\
\text { MSW } \\
\text { MSSL } \\
\text { MSSW } \\
\text { MSGN }\end{array}$ & 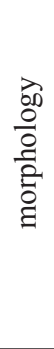 & $\begin{array}{l}\text { MSGW } \\
\text { MSTGW } \\
\text { LSDW } \\
\text { LSN } \\
\text { PLSN } \\
\text { LSW } \\
\text { LSGN } \\
\text { LSGW } \\
\text { LSTGW }\end{array}$ \\
\hline
\end{tabular}

Significant differences in the level of relative water content and water saturation deficit were obtained between the tested rye lines in control and those subjected to stress conditions. On day 18 of drought, the water content in tissues was reduced by $31.7 \%$ relative to the control (Fig. 1). The duration of the stress conditions resulted in an increase of the water saturation deficit by $17.3 \%$ in the tested rye line (Fig. 1).

The tested rye line did not exhibit any considerable variability of the maximum quantum efficiency of PS II (Fv/Fm). In stress conditions, the value of the maximum photochemical efficiency of PSII was $95.5 \%$ as compared to the control (Fig. 1). On day 18 of drought, the reduction of the maximum photochemical efficiency of PSII was $8.8 \%$, relative to day 12 of drought. Kalaji et al. (2014) emphasise that the Fv/Fm parameter is not sensitive to drought stress. Similar results were obtained for other plant species in variable conditions of water stress intensity (Havaux 1992, Cechin 1998, Klamkowski et al. 2015, Czyczyło-Mysza and Myśków 2017). 
Under the influence of water deficiency, the possibility of damaging the PS II photosystem increases. The decrease of the maximum photochemical efficiency of PS II indicates a reduced demand of the plant for the products constituting the so-called assimilation force and disturbances in the photosynthesis process (Faraloni et al. 2011). According to certain authors, the overall performance index of PS II appears to be one of the sensitive indices of the effect of stress factors on plants (Rapacz 2007, Rapacz and Woźniczka 2009, Czyczyło-Mysza 2013). In the conducted study, an unfavourable influence of drought on the efficiency of PSII performance in the tested rye line was found. Because of the drought, the PSII performance index was reduced, and the decrease tendency of the PI value was intensified with the duration of the stress period. In stress conditions, the PI value was $68.5 \%$ as compared to the control (Fig. 1). On day 18 of drought, the reduction in the PSII functioning index was $33.7 \%$, compared to day 12 of drought. Similar results in two inbred rye lines after 28 days of drought were obtained by Czyczyło-Mysza and Myśków (2017). Changes in the time of attaining maximal chlorophyll fluorescence were observed. In stress conditions, in the tested rye line, an increase in the $\mathrm{T}_{\mathrm{FM}}$ value, relative to control, was observed. Moreover, an increase tendency was observed for the $\mathrm{T}_{\mathrm{FM}}$ along with the time of the stress conditions. On day 18 of drought, the $\mathrm{T}_{\mathrm{FM}}$ value was $23.4 \%$ higher than on day 12 of the stress (Fig. 1). The value of this parameter was higher when the period of the stress to which the plant was exposed was longer (Cetner et al. 2016). The Fv value was not subject to larger changes for rye in the control. In the drought conditions, variable fluorescence exhibited a decreasing tendency in comparison to the control (Fig. 1). The Fv value in GULbw line in drought conditions was reduced by $26.5 \%$, compared to the control. Lower values of this parameter indicate a reduced efficiency of the PSII photosystem (Cetner et al. 2016).

Statistically significant differences between well-watered and stressed plants were noted for the following morphological characteristics: SN, PH, LSDW, PLSN, LSW, LSGN, and LSGW. All morphological traits values, excluding SN, decreased due to drought (Fig. 2). Many researchers confirmed that water stress leads to growth reduction, which is reflected in the plant height, dry weight, and other growth functions. Greater tillering is rarely observed; however, it was shown to be an adaptation to low-stress conditions of winter wheat (Duggan et al. 2000). The ability of winter wheat to produce large numbers of tillers was evident in the spring, but this early season potential was not maintained due to extensive tiller die-back (Duggan et al. 2000). We observed a similar situation; many tillers of stressed plants bore no heads and the number of productive stalks was lower compared to control plants.

The stalk number of all tillers (with and without heads) was strongly negatively correlated to the plant height $(-0.97)$. SN and PH were significantly associated with RWC ( -0.89 and 0.91 , respectively) and with WSD, inversely. Positive and significant correlation between RWC and plant height was observed previously for 
wheat (Jatoi et al. 2011). The stalk number of all tillers (with and without heads) was strongly negatively correlated to the plant height $(-0.97)$. SN and $\mathrm{PH}$ were significantly associated with RWC ( -0.89 and 0.91 , respectively) and with WSD, inversely. Positive and significant correlation between RWC and plant height was observed previously for wheat (Jatoi et al. 2011).
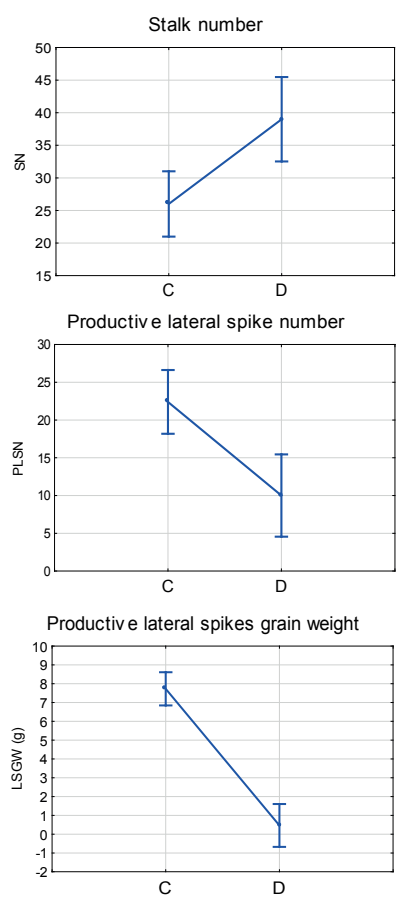
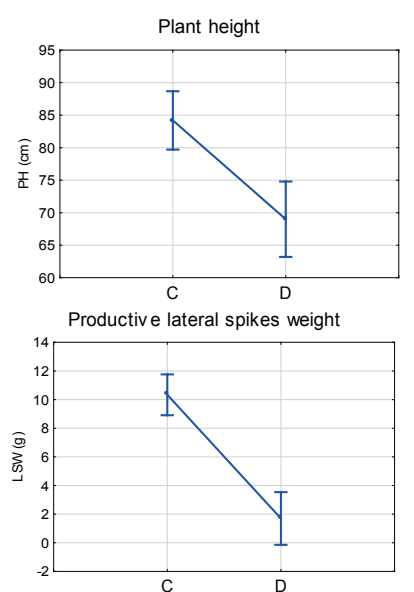
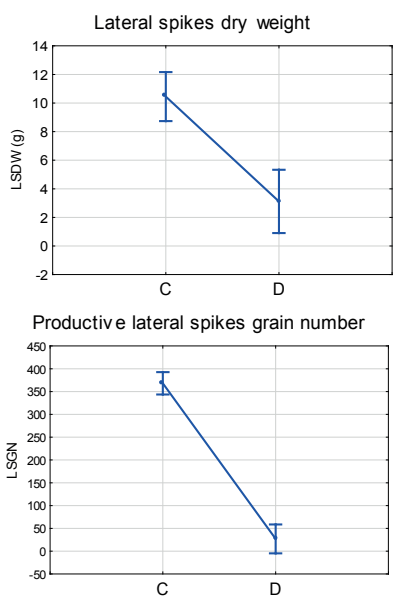

Fig. 2. Morphological traits showing significant differences (Duncan test, $p=0.01$ ) between rye plants of inbred line GULbw grown in well-watered conditions (C) and under drought stress (D). Vertical lines -0.95 confidence levels

Correlation of morphological and physiological characteristics was also found, mainly for spikes/grains number and weight, and gas exchange parameters. A significant positive value of coefficient $r$ was found between PLSN, LSW, LSGN, LSGW, and E, gs, ci (0.90-0.98). The same morphological characteristics revealed a negative correlation with $\mathrm{T}_{\mathrm{FM}}$, ranged from -0.91 to -0.86 .

PCA analysis was performed for the physiological and morphological traits of plants of two experiment variants (C and $\mathrm{D})$. Because of numerous characteristics analysed, the data were divided into four groups (Fig. 3): assimilation pigments, gas exchange, water balance, and fluorescence parameters. In all the cases, the data demonstrated high variability, for PC1 it ranged from 60 to $67 \%$ and $14-16 \%$ for PC2. Physiological parameters analysed separately showed 70\% for PC1 and 16\% for PC2, and morphological traits were $63 \%$ and $15 \%$, respectively (data not shown). 


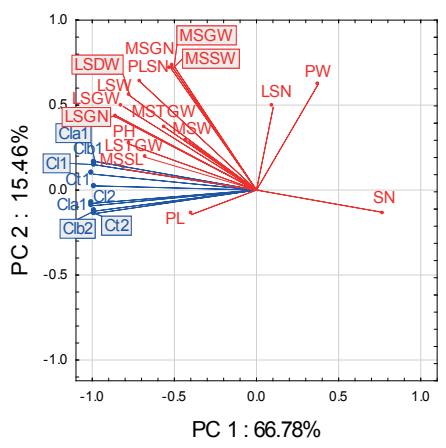

C

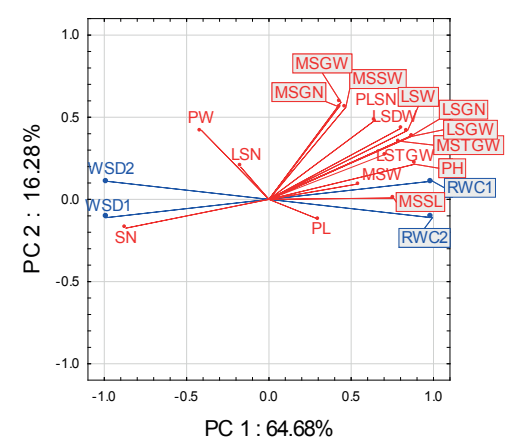

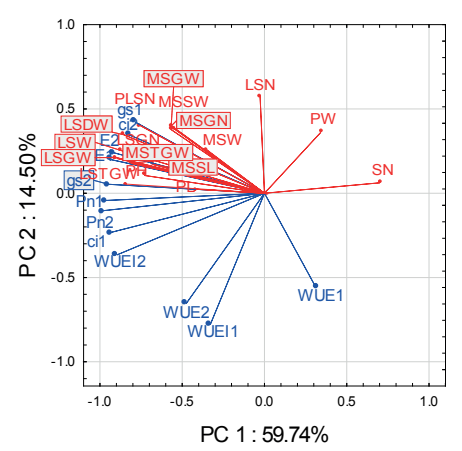

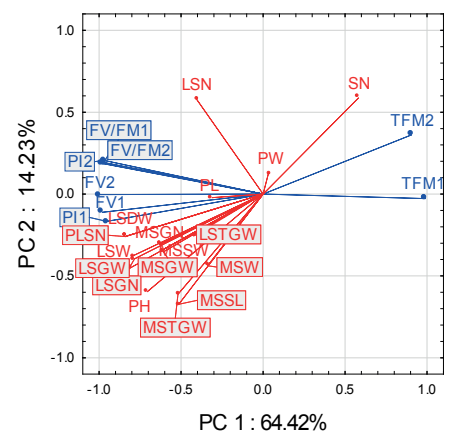

Fig. 3. Vector view of biplot showing interrelationships among studied traits. Morphological traits are marked in red colour. Blue colour is for photosynthesis characteristics: A - assimilation pigments, $\mathrm{B}$ - gas exchange parameters, $\mathrm{C}$ - water balance parameters, D - fluorescence parameters. An acute angle between the measured parameters means positive correlation, obtuse angle - negative correlation, right angle - no correlation; PC1 - principal component 1, PC2 - principal component 2 . Each variable is represented by a vector. The direction and length of vectors determine to what extent individual variables affect the main components. The longer they are, and the closer the variables are to the circle, the greater part of the information contained in an input variable is carried by the main components

\section{CONCLUSIONS}

1. Significant differences in the level of relative water content and water saturation deficit were obtained between the tested rye lines in control and those subjected to stress conditions.

2. Net photosynthesis and transpiration intensity in the GULbw line in drought conditions was reduced by 24.5 and $22.3 \%$, respectively, relative to the intensity of these processes in the control plant. 
3. Because of the drought, the PSII performance index was reduced, and the decrease tendency of the PI value was intensified with the duration of the stress period. In stress conditions, the PI value was $68.5 \%$ as compared to the control.

4. The inbred line of GULbw rye reacted with quite a significant reduction of photosynthetic activity. This demonstrates the high sensitivity of the photosynthetic apparatus of this variety of plants to the stress caused by the lack of water in the substrate.

\section{REFERENCES}

Anjum F., Yaseen M., Rasul E., Wahid A., Anjum S., 2003. Water stress in barley (Hordeum vulgare L.). II. Effect on chemical composition and chlorophyll contents”. Pakistan J Agric Sci., 40, 45-49.

Anjum S.A., Xie X-Y., Wang L-Ch., Saleem M.F., Man Ch., Lei W., 2011. Morphological, physiological and biochemical responses of plants to drought stress. Afr. J. Agric. Res., 6(9), 2026-2032.

Arji I., Arzani K., 2008. Effect of water stress on some biochemical changes in leaf of five olive (Olea europaea L.) cultivars. Acta Horticulturae, 791, 523-526, doi:10.17660/ActaHortic.2008.791.80

Arnon D.J., Allen M.B., Whatley F., 1956. Photosynthesis by isolated chloroplast. IV General concept and comparison of three photochemical reactions. Biochim. Biophys. Acta, 20, 449-461, doi:10.1016/0006-3002(56)90339-0

Bandurska H., 1991. The effect of proline on nitrate reductase activity in water - stressed barley leaves. Acta Physiol. Plant., 1, 3-11.

Blum A., 2009. Effective use of water (EUW) and not water-use efficiency (WUE) is the target of crop yield improvement under drought stress. Field. Crop. Res., 112, 119-123, doi:10.1016/j.fcr.2009.03.009

Bray E., 1997. Plant responses to water deficit. Trends Plant Sci. 2, 48-54, doi:10.1016/S1360-1385 (97)82562-9

Cechin I., 1998. Photosynthesis and chlorophyll fluorescence in two hybrids of sorghum under different nitrogen and water regimes. Photosynthetica., 35, 233-240, doi:10.1023/A:1006910823378

Cetner M.D., Dąbrowski P., Samborska I.A., Łukasik I., Swoczyna T., Pietkiewicz S., Bąba W., Kalaji M.H., 2016. Application of chlorophyll fluorescence measurements in environmental studies (in Polish). Kosmos. Probl. Nauk Biol., 65(2/311), 197-205.

Cetner M.D., Pietkiewicz S., Podlaski S., Wiśniewski G., Chołuj D., Łukasik I., Kalaji M.H., 2014. Photosynthetic Efficiency of Virginia Mallow (Sida Hermaphrodita (L.) Rusby) under Differentiated Soil Moisture Conditions. Int. J. Sust. Water Environ. Syst. 6, 89-95.

Czyczyło-Mysza I., 2013. Identification of quantitative trait loci (QTL) controlling photochemical and photosynthetic activity and yield of wheat plants under drought conditions using a mapping population of CSDH lines. Dissertation, PAS.

Czyczyło-Mysza I., Myśków B., 2017. Analysis of the impact of drought on selected morphological, biochemical and physiological traits of rye inbred lines. Acta Physiol. Plant., 39, 87-94, doi:10.1007/s11738-017-2385-x

Desotgiu R., Pollastrini M., Cascio C., Gerosa G., Marzuoli R., Bussotti F., 2012. Chlorophyll a fluorescence analysis along a vertical gradient of the crown in a poplar (Oxford clone) subjected to ozone and water stress. Tree Physiology., 32, 976-986, doi:10.1093/treephys/tps062

Duggan B.L., Domitruk D.R., Fowler DB., 2000. Yield component variation in winter wheat grown under drought stress. Can. J. Pl. Sci., 80, 739-745, doi:10.4141/P00-006 
Faraloni C., Cutino I., Petruccelli R., Leva A.R., Lazzeri S., Torzillo G., 2011. Chlorophyll fluorescence technique as a rapid tool for in vitro screening of olive cultivars (Olea europaea L.) tolerant to drought stress. Environ. Exp. Bot., 73, 49-56, doi:10.1016/j.envexpbot.2010.10.011

Hager A., Mayer-Berthenrath T., 1966. Die Isolierung und quanttative Bestimung der Carotenoide und Chlorophyll von Blatern, Algen und isolierten Chloroplasten mit Hilfe Dunnschichtchromatographischer Methoden. Planta. 69, 198-217, doi:10.1007/BF00384873

Havaux M., 1992. Stress tolerance of photosystem II in vivo, antagonistic effects of water, heat and photoinhibition stresses. Plant Physiol., 100, 424-432, doi:10.1104/pp.100.1.424

Jaleel C.A., Manivannan P, Wahid A, Farooq M., Somasundaram R., Panneerselvam R., 2009. Drought stress in plants: a review on morphological characteristics and pigments composition. Int. J. Agric. Biol., 11, 100-105.

Jaroszewska A., Podsiadło C., Kowalewska, R., 2011. Analysis of water use by cherry tree under various water and fertilisation conditions (in Polish). Infrastruktura i Ekologia Terenów Wiejskich, 6, 165-173.

Jatoi W.A., Baloch M.J. Kumbhar M.B., Khan N.U., Kerio M.I., 2011. Effect of water stress on physiological and yield parameters at anthesis stages in elite spring wheat cultivars. Sarhad J. Agric., 27(1), 59-65.

Kalaji H.M., Carpentier R., Allakhverdiev S.I., Bosa K., 2012. Fluorescence parameters as early indicators of light stress in barley. J. Photoch. Photobio. B., 112, 1-6, doi:10.1016/j.jphotobiol. 2012.03.009

Kalaji H.M., Oukarroum A., Alexandrov V., Kouzmanova M., Brestic M., Zivcak M., Samborska I.A., Cetner M.D., Allakhverdiev S.I., Goltsev V., 2014. Identification of nutrient deficiency in maize and tomato plants by in vivo chlorophyll a fluorescence measurements. Plant Physiol. Biochem., 81, 16-25, doi:10.1016/j.plaphy.2014.03.029

Kiani S.P., Maury P., Sarrafi A., Grieu P., 2008. QTL analysis of chlorophyll fluorescence parameters in sunflower (Helianthus annuus L.) under well-watered and water-stressed conditions". Plant Sci., 175, 565-573, doi:10.1016/j.plantsci.2008.06.002

Klamkowski K., Treder W., Orlikowska T., 2015. Effect of long-term water deficit in the substrate on selected physiological parameters of plants of three raspberry cultivars (in Polish). Inf. Ecol. Rural Areas, 3(1), 603-611.

Kocoń A., 2006. Effect of water stress on photosynthesis of selected spring wheat cultivars (in Polish). Zesz. Probl. Postęp. Nauk Rol., 509, 133-139.

Lichtenthaler H.K., 1987. Chlorophylls and carotenoids: Pigments of photosynthetic biomembranes. Methods Enzymol., 148, 350-380, doi:10.1016/0076-6879(87)48036-1

Mahajan S., Tuteja N., 2005. Cold, salinity and drought stresses: an overview. Arch. Biochem. Biophys., 444, 139-158, doi:10.1016/j.abb.2005.10.018

Massacci A., Nabiev S.M., Pietrosanti L., Nematov S.K., Chernikova T.N., Thor K., Leipner J., 2008. Response of the photosynthetic apparatus of cotton (Gossypium hirsutum) to the onset of drought stress under field conditions studied by gas-exchange analysis and chlorophyll fluorescence imaging. Plant Physiol. Biochem., 46, 189-195, doi:10.1016/j.plaphy.2007.10.006

Mishra K.B., Iannacone R., Petrozza A., Mishra A., Armentano N., La Vecchia G., Trtílek M., Cellini F., Nedbal L., 2012. Engineered drought tolerance in tomato plants is reflected in chlorophyll fluorescence emission. Plant Sci., 182, 79-86, doi:10.1016/j.plantsci.2011.03.022

Morales C.G., Pino M.T., del Pozo A., 2013. Phenological and physiological responses to drought stress and subsequent rehydration cycles in two raspberry cultivars. Sci. Hort., 162, 234-241, doi:10.1016/j.scienta.2013.07.025 
Neill S.J., Burnett E.C.,1999. Regulation of gene expression during water deficit stress. Plant Growth Reg., 29, 23-33, doi:10.1023/A:1006251631570

Olszewska M., 2004. Response of white clover grown on two types of soils to water stress (in Polish). Acta Sci. Pol., Agricultura, 3(2), 203-213.

Olszewska M., Grzegorczyk S., 2013. Effect of water stress on selected grass cultivars grown on an organic soil (in Polish). Fragm. Agron., 30(3), 140-147.

Olszewski J., Pszczółkowska A., Kulik T., Fordoński G., Płodzień K., Okorski A., Wasielewska J., 2007. Effect of water deficit on gas exchange indices, productivity and health status of winter wheat cultivars (in Polish). Acta Sci. Pol., Agricultura, 6(4), 33-42.

Popova L.P., Outlaw W.H., Aghoram K., Hite D.R.C., 2000. Abscisic acid - an intraleaf water-stress signal. Physiol. Plant., 108, 376-381.

Ranjbarfordoei A., Samson R., Van Damme P., Lemeur R., 2000. Effects of drought stress induced by polyethylene glycol on pigment content and photosynthetic gas exchange of Pistacia khinjuk and P. mutica. Photosynthetica, 38, 443-447, doi:10.1023/A:1010946209484

Rapacz M., 2007. Chlorophyll a fluorescence transient during freezing and recovery in winter wheat. Photosynthetica, 45, 409-418, doi:10.1007/s11099-007-0069-2

Rapacz M., Woźniczka A., 2009. A selection tool for freezing tolerance in common wheat using the fast chlorophyll a fluorescence transient. Plant Breed., 128, 227-234, doi:10.1111/ j.1439-0523.2008.01566.x

Rekika D., Nachit M.M., Araus J.L., Monneveux P., 1998. Effects of water deficit on photosynthetic rate and osmotic adjustment in tetraploid wheats. Photosynthetica, 35, 129-138, doi:10.1023/A:1006890319282

Richards R.A., 2006. Physiological traits used in the breeding of new cultivars for water-scarce environments. Agric. Water Manag., 80, 197-211, doi:10.1016/j.agwat.2005.07.013

Starzycki S., 1976. Diseases Pests and Physiology of Rye. In: Production, Chemistry and Technology (Ed. W. Bushuk). American Association of Cereal Chemists, St. Paul, 27-61.

Stoll M., Jones H.G., Infante J.M., 2002. Leaf gas exchange and growth in red raspberries is reduced when part of the root system is dried. Acta Hort., 585, 671-676, doi:10.17660/ ActaHortic.2002.585.111

Yordanov I., Velikova V., Tsonev T., 2000. Plant response to drought, acclimation and stress tolerance. Photosynthetica, 38, 171-186, doi:10.1023/A:1007201411474

Yordanov I., Velikova V., Tsonev T., 2003. Plant responses to drought and stress tolerance. Bulg. J. Plant Physiol., 187-206.

Zlatev Z., 2009. Drought-induced changes in chlorophyll fluorescence of young wheat plants. Biotechnology, 23, 438-441, doi:10.1080/13102818.2009.10818458 


\title{
ZMIANY I ZALEŻNOŚCI PARAMETRÓW FIZJOLOGICZNYCH I MORFOLOGICZNYCH ŻYTA PODDANEGO STRESOWI SUSZY GLEBOWEJ
}

\author{
Katarzyna Monika Malinowska ${ }^{1}$, Beata Myśków ${ }^{2}$, Ilona Czyczyło-Mysza ${ }^{3}$, \\ Magdalena Góralska \\ ${ }^{1}$ Katedra Fizjologii Roślin i Biochemii, WKŚiR \\ Zachodniopomorski Uniwersytet Technologiczny w Szczecinie \\ ul. Słowackiego 17, 71-434 Szczecin \\ ${ }^{2}$ Katedra Genetyki, Hodowli i Biotechnologii Roślin \\ Zachodniopomorski Uniwersytet Technologiczny w Szczecinie \\ ul. Słowackiego 17, 71-434 Szczecin \\ ${ }^{3}$ Instytut Fizjologii Roślin, Polska Akademia Nauk \\ ul. Niezapominajek 21, 30-239 Kraków
}

Streszczenie. Celem badań była ocena wpływu stresu suszy na sprawność aparatu fotosyntetycznego żyta odmiany Gulz, którą oceniono na podstawie pomiarów parametrów fluorescencji chlorofilu oraz wymiany gazowej, bilansu wodnego, barwników asymilacyjnych i parametrów morfologicznych. Eksperyment przeprowadzono na linii wsobnej żyta GULbw (oryginalna nazwa: Gülzow 661-67, numery akcesyjne: GueR 412, R 1599), uzyskanej z banku genów Federalnego Banku Genów dla Rolniczych i Ogrodniczych Gatunków Roślin z Leibniz, Instytut Genetyki Roślin i Badań Roślin Uprawnych (IPK) Gatersleben, Niemcy. W wyniku suszy zmniejszył się wskaźnik funkcjonowania PS II (fotosystem PS II), przy czym tendencja spadkowa wartości PI (ogólny wskaźnik funkcjonowania PS II) nasilała się wraz z długością trwania warunków stresu. Testowana linia żyta w kontroli nie wykazała znaczącej zmienności maksymalnej wydajności kwantowej PS II (Fv/Fm). Istotne różnice w natężeniu transpiracji, przewodności szparkowej i podszparkowego stężenia $\mathrm{CO}_{2}$ stwierdzono w 18 dniu suszy. Zauważono istotną dodatnią zależność współczynników korelacji pomiędzy PLSN, LSW, LSGN, LSGW i E, gs, ci (PLSN - liczba kłosów produkcyjnych z pędów bocznych, LSW masa kłosów produkcyjnych z pędów bocznych, LSGN - liczba ziaren z pędów bocznych, LSGW - masa ziaren z pędów bocznych, $\mathrm{E}$ - intensywność transpiracji, ci - podszparkowe stężenie $\mathrm{CO}_{2}$, gs - przewodnictwo szparkowe).

Słow a kluczowe: morfologia, fotosynteza, Secale cereale L. 